------ Iraqi National Journal of Earth Sciences, Vol. 11, No. 2, pp. 51-64, $2011-------$

\title{
Hypogene Processes of the Gypsum Beds in Sangaw Sinkholes, Kurdistan Region, NE-Iraq
}

\author{
Bakhtyar M. Ameen \\ Department of Geology \\ College of Science \\ University of Sulaimani
}

(Received 26/9/2010, Accepted 30/12/2010)

\begin{abstract}
The Sangaw region is located at the western part of Zagros orogenic belt at the boundary between Low and High Folded Zones, Sulaimani governorate in Kurdistan region. The area characterized by low amplitude folds that are trending northwest southeast and arranged in en echelon pattern. The exposed formations are Eocene Pila Spi (limestone), middle Miocene Fat ha(lagoon) and Upper Fars (clastics) formations. Many large and small sinkholes are found around Ashdagh anticline; some of them about $50 \mathrm{~m}$ in diameter and about $30 \mathrm{~m}$ deep. Some are developed into complicated cave systems with collaps blocks and breccias in addition to narrow passages and fissures. The largest of them is located directly to the west of Darzilla village at the southeastern plunge of Ashdagh anticline. The sinkholes occur in Fat ha and in the Pila Spi Formations. The walls of the sinkholes are covered by secondary gypsum, sulfur, bitumen and secondary calcite. Inside the cave collapse, breccias and blocks with lensoidal stratified clayey sediments as weathering product could be seen. The water is acidic $(\mathrm{pH}=4)$ inside the caves and discharges as large spring $(200 \mathrm{~L} / \mathrm{S})$ with white milky color; it is called in the local Kurdish language, "Awa Spi "which means white stream. The weathering of the carbonate rocks is intense inside the cave and appears as honeycombs and rills mark which have very rough surface with dull color. The sinkholes were produced from the dissolution of thick gypsum and limestone beds. The origin of these caves has been proposed to be hypogenic speleogenesis due to the presence of gypsum and bitumen. These materials with the aid of bacteria enrich the water with $\mathrm{H}_{2} \mathrm{~S}$ which aciditfies the water and precipitates the sulfur and secondary gypsum on the cave wall. The formation of $\mathrm{H}_{2} \mathrm{SO}_{4}$ by oxidaton of $\mathrm{H}_{2} \mathrm{~S}$ is the main reason that aid the sinkhole hypogene generation in Sangaw area. A realistic model is drawn to interpret and connect the following:

1- The stratigraphy and structure of the area encourage the generation of underground stagnant pond suitable for reacting with the emanating $\mathrm{H}_{2} \mathrm{~S}$ necessary for the hypogene generation of the sinkholes and precipitation of secondary native sulfur
\end{abstract}


and gypsum.2- dissolution of gypsum and its reduction by bacteria. 3- upward migration of bitumen from nearby oil traps(hydrocarbon accumulation).

\section{عمليات الهايبوجين في طبقات الجبس في منخسفات سنكاو، أقليم كردستان شمال شرق العراق}

$$
\text { بختيار محمد أمين }
$$

\section{الملخص}

تقع منطقة سـنكاو في الجزء الغربي من حزام زاكروس ألأوروجيني على الحد بين نطـاقي الطيات

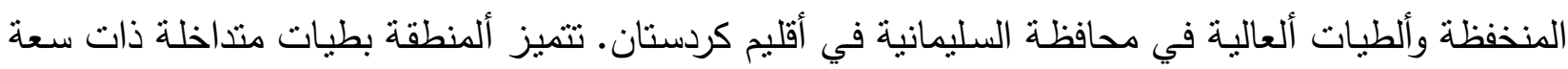
منخفظة تمتد شمال غرب - جنوب شرق. ألنكوينات ألظاهرة في المنطقة هي تكوين ألبيلاسبي (ألأيوسين)

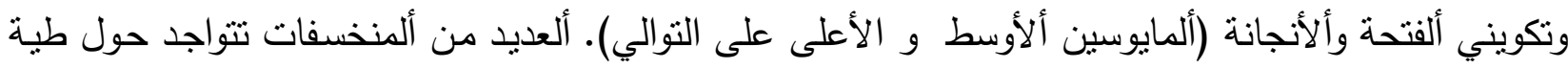

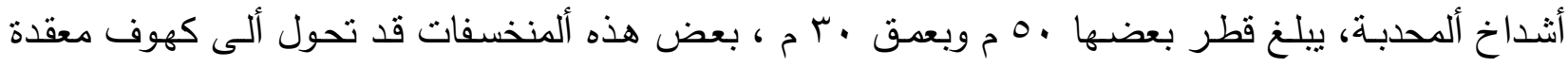

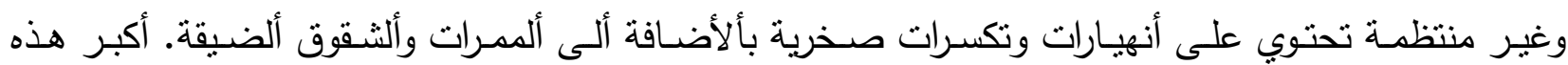

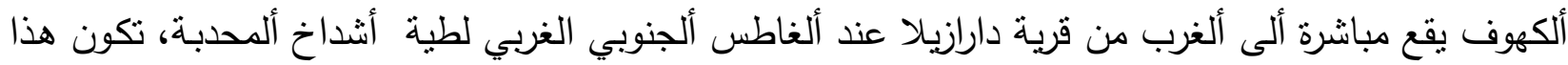

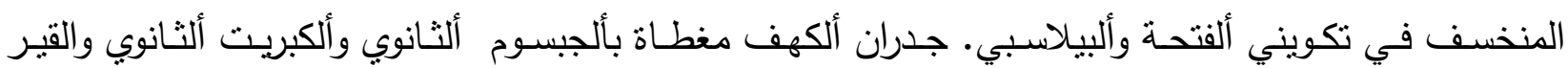

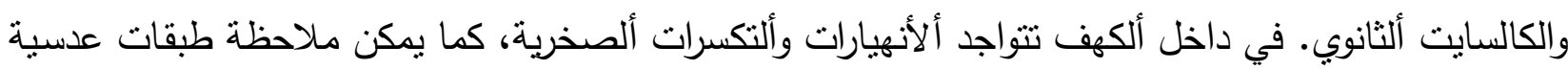

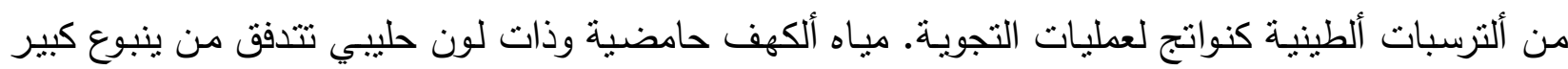

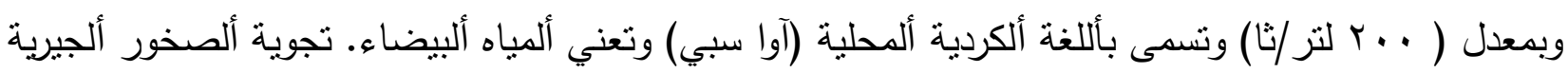

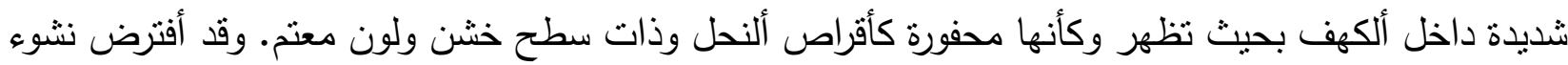

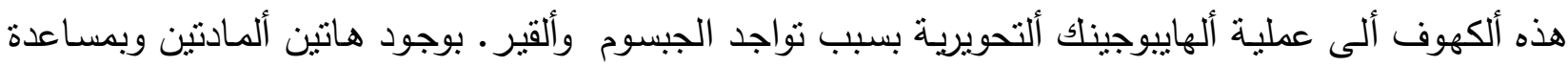

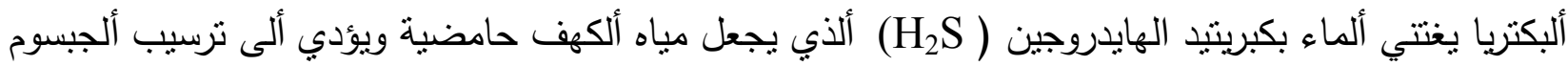
ألثانوي والكبريت ألثانوي على جدران ألكهف. تكون حامض ألكبريتيك (H2SO في الماء وهو السبب ألرئيس لتكون ألمنخسفات ألهاييوجينيه في منطقة سنكاو ـ وقد نم رسم موديل لتفسير 
1 - طباقية وتركيبية ألمنطقة ساعدا في تكوين برك تحت أرضية راكدة وملائمة لعليات ألتفاعل مع أنبثاق غاز

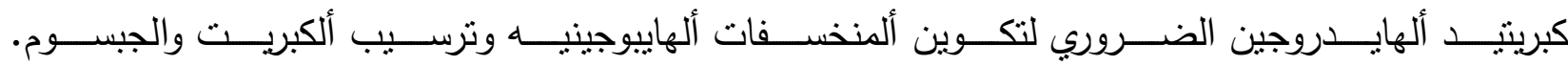

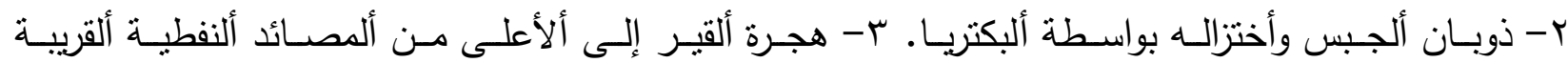
(التجمعات ألهايدروكاربونية).

\section{INTRODUCTION}

The studied area is located within Sulaimaniya Governorate in northeastern Iraq, at an area between High Folded and Foothill Zones. The large sinkhole is located directly at south eastern Ashdagh mountain about $1 \mathrm{~km}$ northwest of Darzilla village (Fig. 1,2)at latitude $35^{\circ} 08^{-} 38^{=} \mathrm{N}, 45^{0} 16^{-} 44^{=} \mathrm{E}$, with elevation $686 \mathrm{~m}$. Other small caves are found around Ashdagh anticline. The sinkholes also exist at the toe of southeastern limb of Sagrma anticline.The sinkholes occur in Fat'ha and Pila Spi Formations. The Fat'ha Formation (previously known as Lower Fars Formation) was, deposited during Middle Miocene evaportitic lagoon and has widespread outcrops in the northeastern Iraq(Fig. 3 A). The formation consists of cyclic alternation of clasticcarbonate-evaporite and marly rocks and it changes mostly to carbonate-evaporites in the basin center. The thicness of gypsum unit in the studied area is about $5 \mathrm{~m}$.

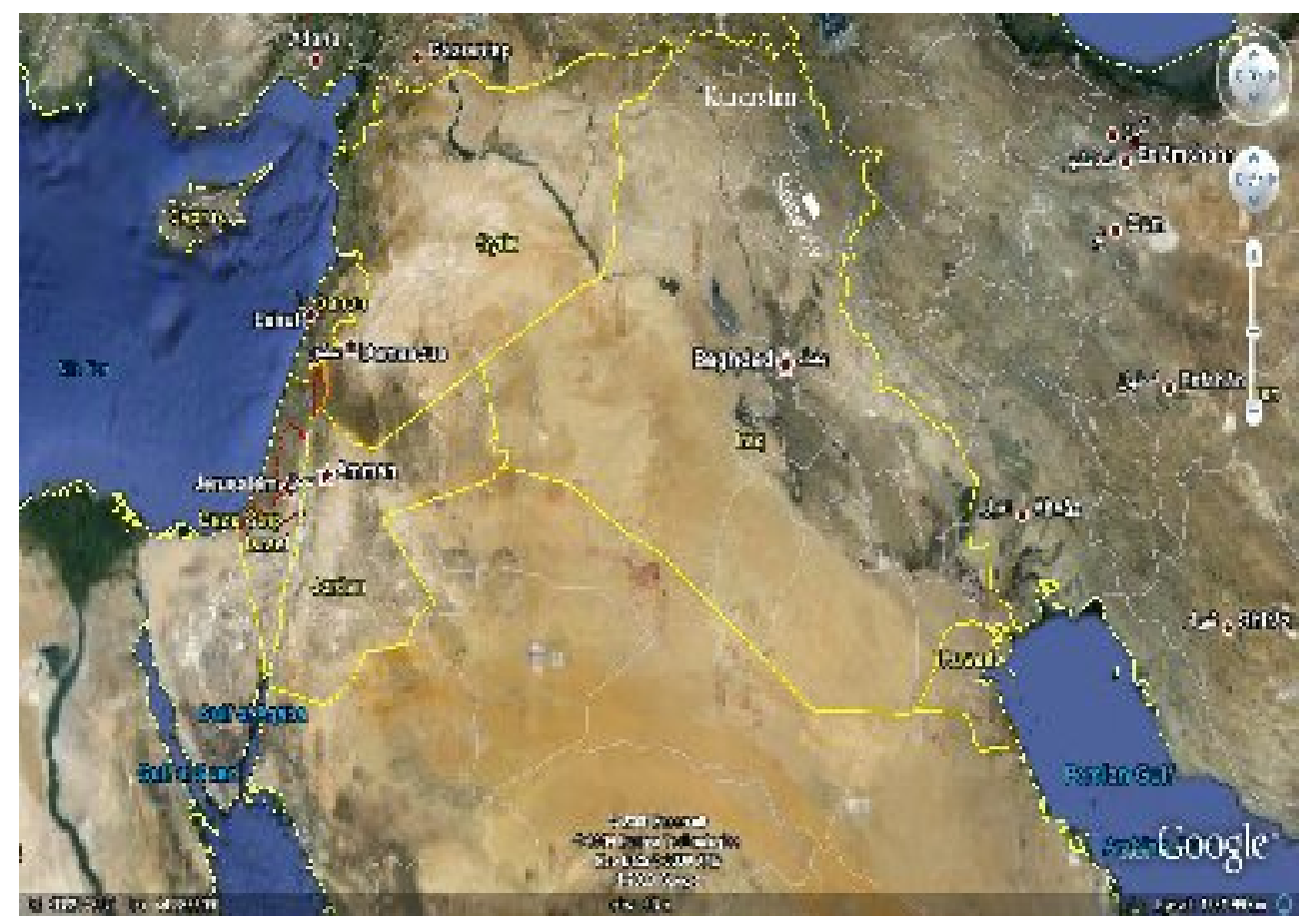

Fig. 1: Google Earth picture of part of middle east, Iraq, Kurdistan region part of NE-Iraq, with approximate location of the Sangaw Sinkhole. 


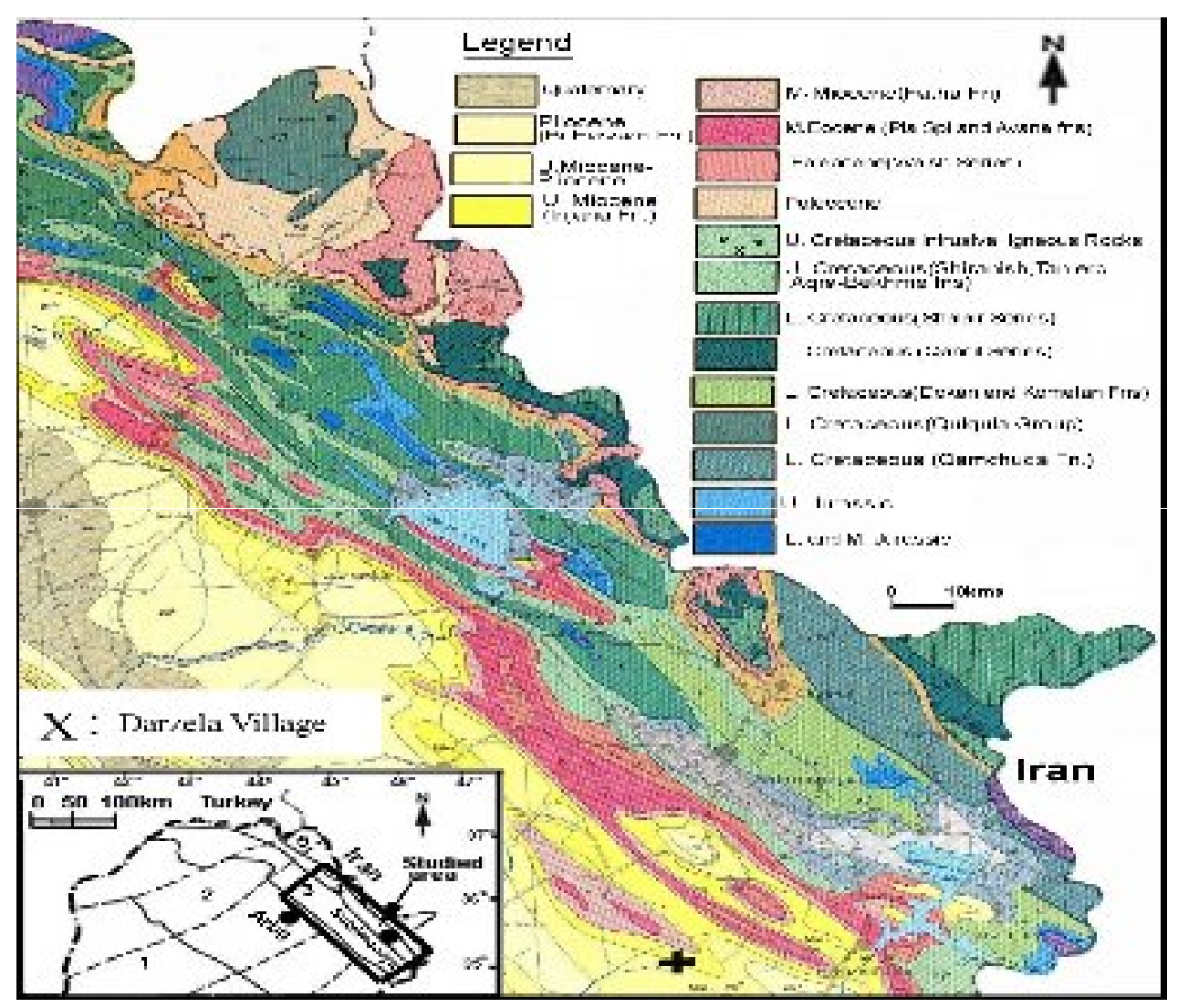

Fig. 2: Geological map of the studied area (Modified from Sissakian, 2000) showing location of the studied area.

The formation was originally described from Iran by (Busk and Mayo, 1918) ( in Bellen et al, 1959). Dunnington (1958) has drawn isopach Facies map for the distribution of the formation in Iraq (Fig. 3B). In the basin periphery, the strata of the formation are onlapping unconformably on either Late Eocene Pila Spi Formation or on the Oligocene units. The upper contact is gradational with Upper Fars Formation and most probably (somewhat) diachronous (Bellen et al, 1959). Due to this onlapping the formation is missing in most parts of the High Folded Zone. The formation in the studied area mainly consists of cyclic repetition of red claystone, marl, gypsum and occasional limestone and sandstone. The maximum thickness of the formation reaches up to $600 \mathrm{~m}$ in the central depositional area, which is lying on the Foothill Zone (Buday, 1980). The lower contact of the Fat'ha Formation is mostly unconformable with Pila Spi Formation in the northeastern margin area (Buday, 1980, 280p). 


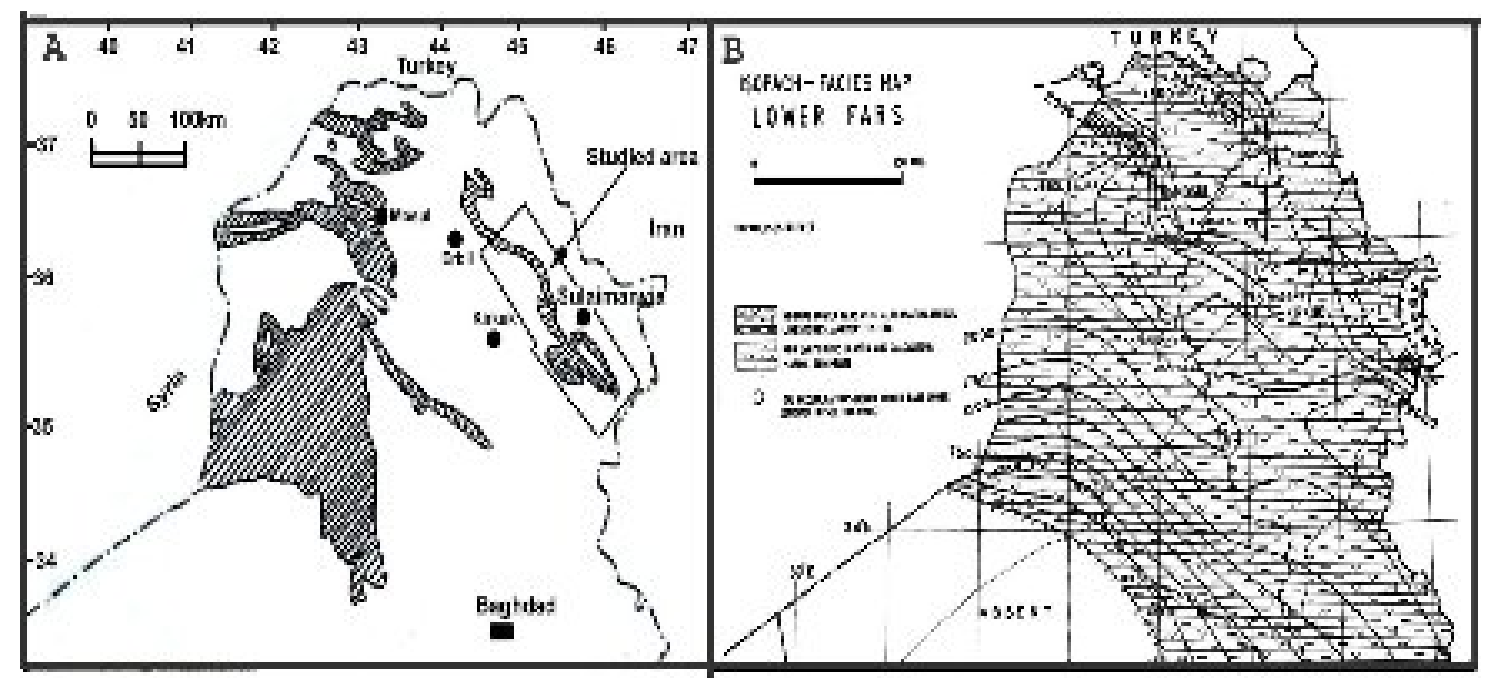

Fig. 3 A: Location map of the studied area and outcrops distribution of the Fat ha (Lower Fars) Formation (modified from Sissakian, 2000).

B: Isopach-Facies map of Lower Fars Formation (Dunnington, 1958).

Maala (2009) studied the karst development in Hadher plain of Iraqi Al-jazera Area; he designated the development due to the collapse of top layer after dissolving of underlying rocks in Euphrates Formation, or due to dissolving of gypsum layer of the Fat ha Formation. Al-Dabbagh and Al-Naqib (2009) studied the sinkholes within the upper part of the upper member of Fat ha Formation at Mosul Dam.

They mentioned that the recent sinkhole is a product of fault crossings. There has been much discussion about the processes involved in the development of hypogene gypsum caves in sedimentary basin, and some has involved caves both in limestone and gypsum in sedimentary basins and caves in deformed limestone (Klimchouk 1996. 2000, 2007).

The Ordinskaya underwater cave which is situated at the district of the Perm region of Russia is the longest gypsum underwater cave in the World; the length of under water passages is more than $4500 \mathrm{~m}$., it belongs to the lrenskiy region of gypsum and gypsum-carbonate karst (Lavrove,1999, Lavrove et al.,2005) .

The aim of the present study to provide evidence for hypogene speleogenesis in gypsiferous beds and to discuss the associated speleogenetic processes of geological framework in Sangaw area.

\section{GEOLOGICAL SETTING}

The studied area is mainly located at the boundary between High Folded and Foothill Zones (Buday1980, Buday and Jassim 1987, Jassim and Goof 2006). It is bounded to the northeast by high amplitude anticlines, within the High Folded Zone, 
changing gradually to low amplitude anticlines, inside the Foothill Zone. The Fat ha Formation is well exposed at the southwestern limb Zimnako, Gulan, Sagrma anticlines, and Darbandi Bazian. In these localities, the outcrops of the formation form flat irons and stratigraphic ribbons geomorphologic features (Fig. 4). The basin was developed from the basin fill of the Neo-Tethys and collision of the Iranian and Arabian Plates. In the studied area the Fat ha Formation is underlained directly by the Pila Spi Formation and is overlained by the injana Formation. The black acidic water $(\mathrm{pH}=4)$ whach occurs inside the cave (Baba Shekh, 2001), to dissolves a high amounts of milky lime and becamesit self milky water when discharged as a source of Awa Spi river drown in the south of sinkholes, bitumn seepage from older layers is mixed with milky water, (Fig. 8A). due to the normal fault in the area (Fig. 5A).

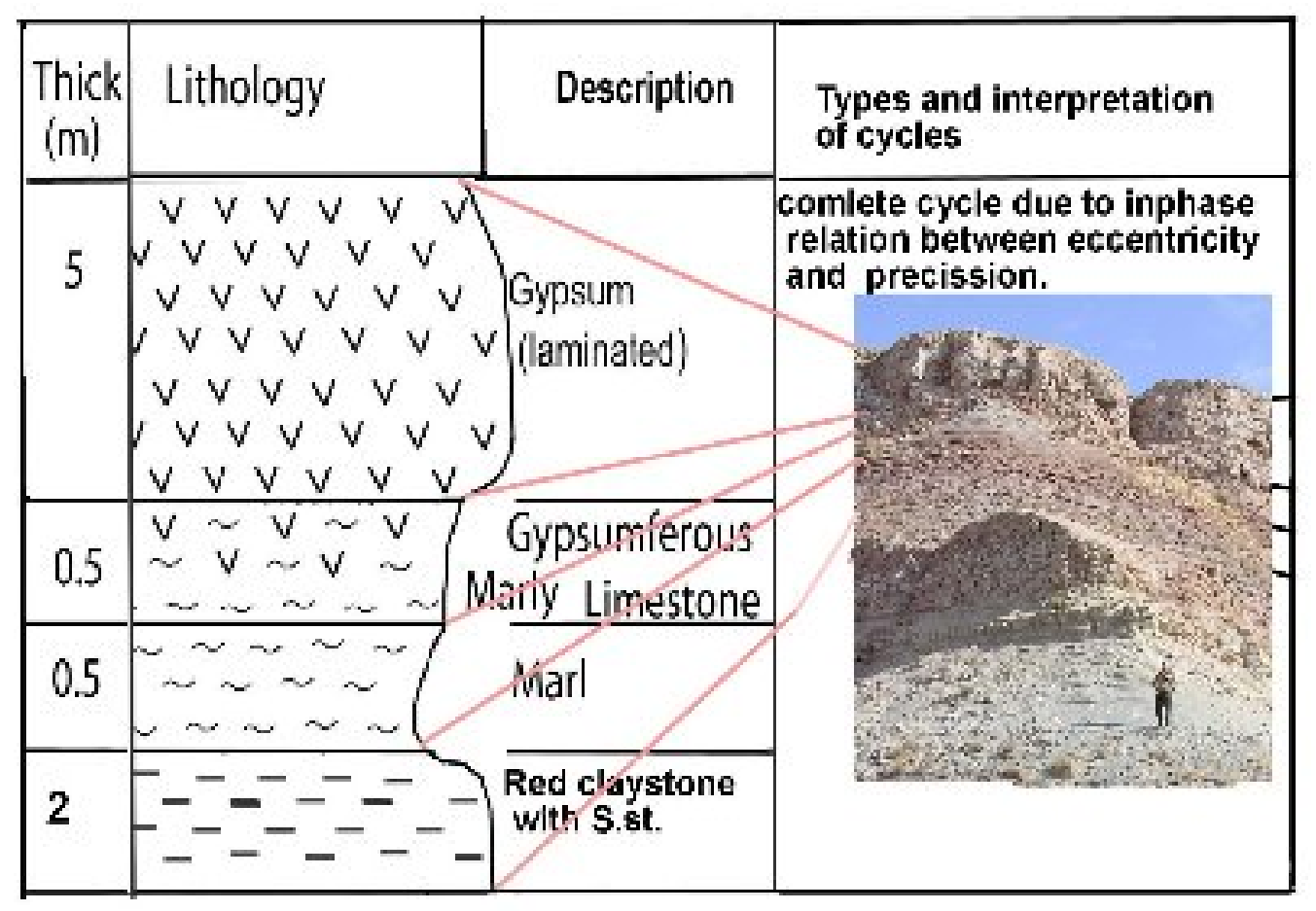

Fig. 4: An ideal cycle of Fat ha Formation at the top of the Awa Spi section for which the lithologies and sequence stratigraphy are shown.

Sometimes blind river could be seen in the studied area due to its disappearance, where the river interflow into some caves then after more than $50 \mathrm{~m}$ reappears especially near Hassan Kalosh village. The area is characterized by the main regional fault (Fig. 5A) and geomorphologically by a series of longitudinal valleys depressions(fig. 6B). All of these sinkholes have relationship with the surface and represent geomorphological features(Fig. 6B). 

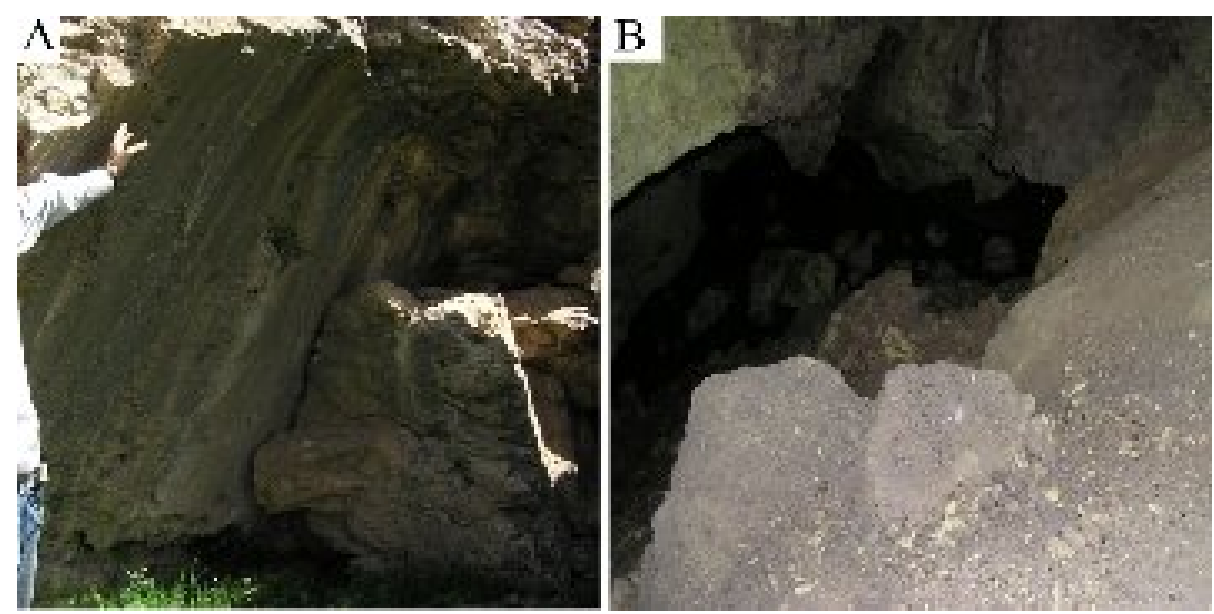

Fig. 5A: Normal Fault at the studied area B: Collaps breccias, Sangaw sinkholes

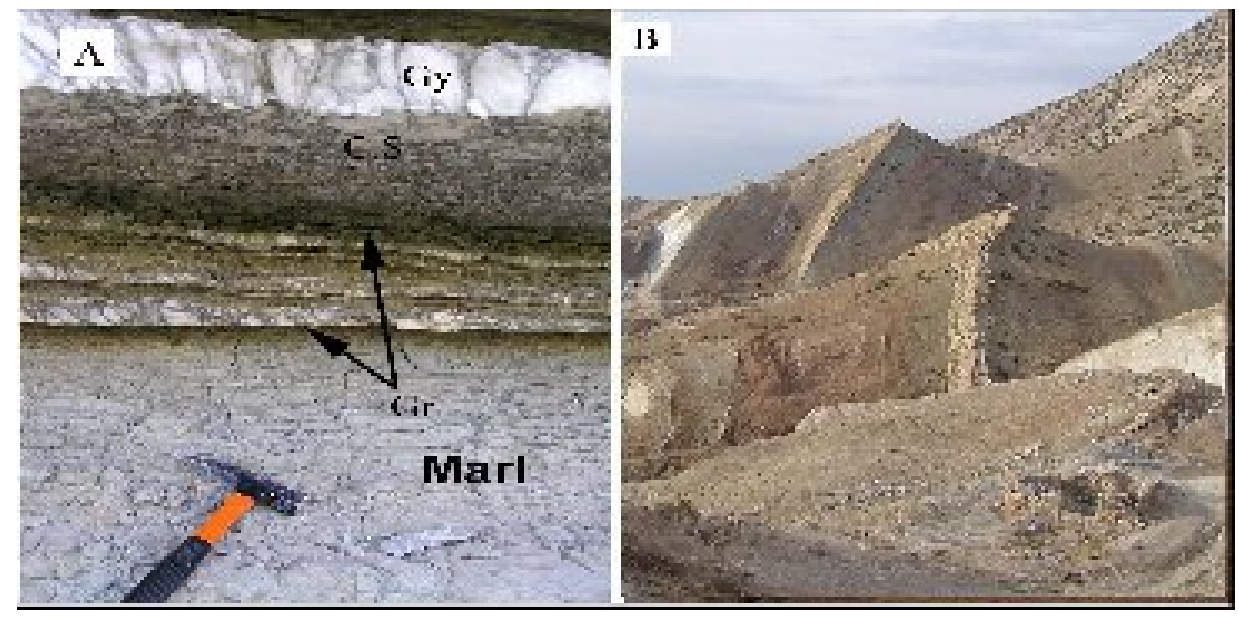

Fig. 6 A: Two ideal cycles of depositions: red claystone (C.S), green marl (Gr) and gypsum (GY) at southeastern plunge of Sagrma anticline. B: Common geomorphologic feature (iron flats) formed by limestone and gypsum beds (southeast limb of Qishlagh anticline).

\section{CHARACTRISTICS OF HYPOGENE CAVES}

The main factors leading to the formation of hypogene caves are the texture of the rocks, climatology and the presence of overlying deposits. The texture is largely responsible for determining the abundance of certain forms with respect to others. Most hypogene and partially hypogene caves are extinct due to the fact that rising fluids are no longer pass through them .Some hypogene caves show evidence of recent activity or contain waters that are slightly elevated in temperature $\left(15^{\circ} \mathrm{C}\right)$, 
aggressive ores are degassing (Dublyansky et al., 2009). In basinal setting the geological structure suggests a source for the fluids responsible for the origin of extinct hypogenic caves (Klimchouk 2007).

Karst features in Sangaw sinkholes occur at the surface outcrops (Fig.7A). Karst collapse sediments consist mainly of breccias and blocks (Fig.5B) with lensoidal stratified clayey sediments as weathering product. The weathering of the carbonate rocks is intense inside the cave and appears as honeycombs and rill marks which have very rough surface with dull color. (Fig.8B). Sangaw sinkholes are of various diameters and depths. The largest sinkhole is about $25 \mathrm{~m}$ high and $50 \mathrm{~m}$ width with $30 \mathrm{~m}$ sub horizontally deepening by three stages. Sangaw sinkhole pattern are recognized by different forms of network cave plains, holes and narrow caves and characterized by blind terminations at the ends of cave segments and show no sign of lateral flow.

Major horizontal and vertical passages at the wall and floor are restricted to a few places with sequence of chambers linked by much smaller passages in Sangaw cave(Fig.7C). The wall cover generally consists of secondary gypsum, sulfur, bitumen and secondary calcite; smaller caves with similar patterns have been reported in the area.
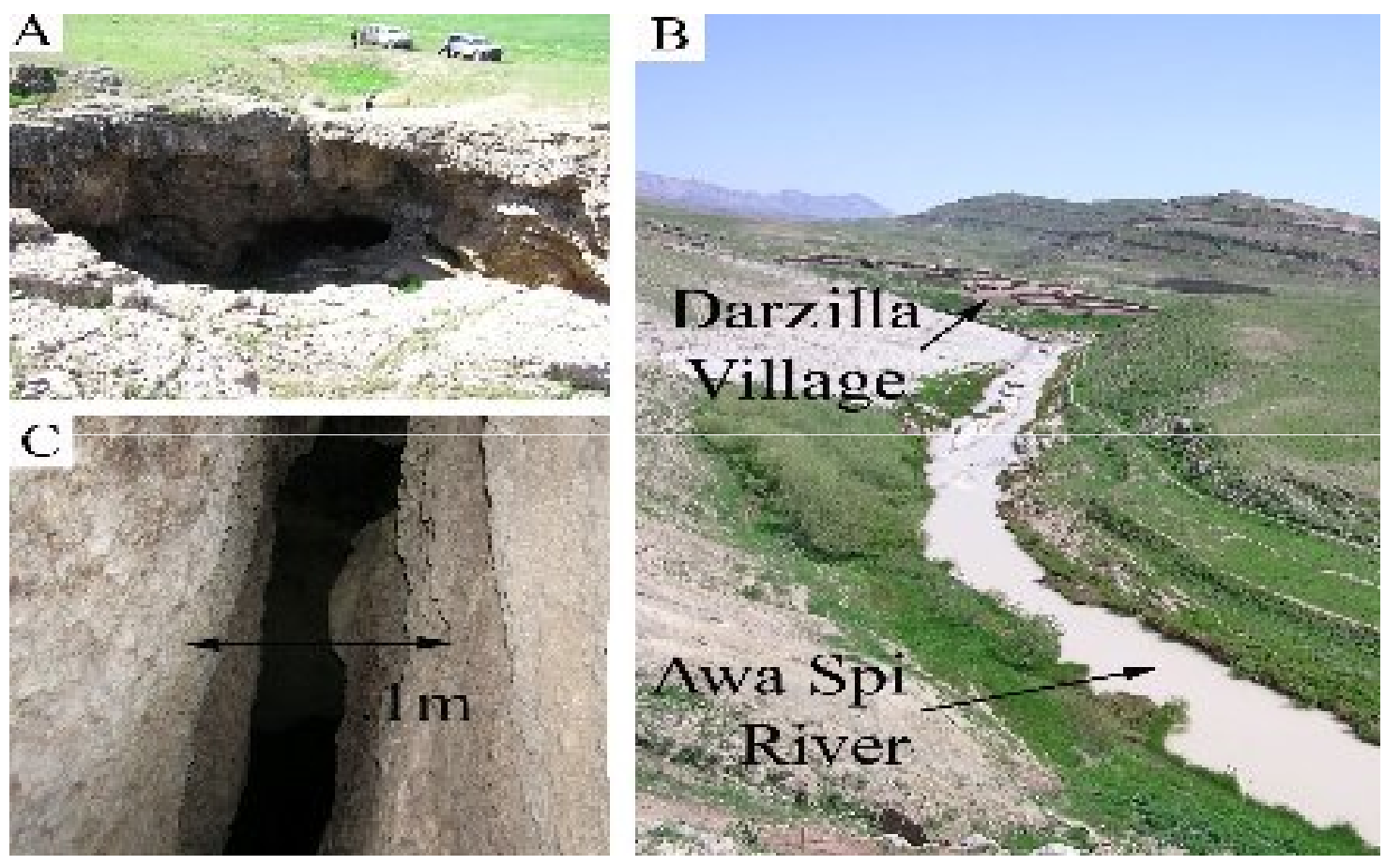

Fig. 7A: The Largest Sinkhole in Sangaw area B: Darzilla Village and Awa Spi river $\mathbf{C}$ : narrow passage linked chambers inside the large sinkhole. 
Hypogene Processes of The Gypsum Beds In Sangaw Sinkholes

\section{GEOLOGICAL CHARACTERIZATION OFGYPSUM KARST OF THE STUDY AREA}

In the characterization of gypsum karst, the intention is to cover virtually all the possibilities from the stratigraphic and structural standpoints. Thus, there is a description of widely varying gypsiferous karsts, made up of Triassic to Miocene materials, some with a complex tectonic configuration and others hardly affected by folding. The gypsiferous karsts described, and their most significant geological characteristics, are as follows (Calaforra , 1998):

1- Karsts in gypsum are composed of gypsiferous levels with the essential characteristic of very continuous marly interstrata between the layers of gypsum, which decisively affect the speleogenesis of the area.

2- Karsts are made up of very chaotic gypsiferous materials containing a large quantity of heterometric blocks of varied composition. The presence of hypersoluble salts at depth is significant in the modification of the hydrochemical characteristics of the water and in the speleogenetic development of the karst.

3- The influence of dolomitic intercalations in the sequence is crucial to the speleogenesis of the area and this, together with intense tectonic activity, has led to the development in this sector of the deepest gypsiferous cavity in the world (Calaforra, 1998).

4- The cavities developed in gypsiferous conglomerates, following structural discontinuities have enabled contact between carbonate and gypsiferous levels, and so we may speak of a mixed karstification: a karst in calcareous rocks and gypsum.

Finally, considering the relation between climatology and the development of karstic forms studied in gypsum in New Mexico (Hill, 2000), where there is an extensive outcrop of Permian gypsum, both micro and macrocrystalline, situated on a large platform almost unaffected by deformation, and where the conditions of aridity are very similar to those found in the gypsiferous karst of Sorbas (SE-Spain). (Kempe, et al,. 2009) studied hypogene krstification of the gypsum beds in Al-Daher cave in northern Jordan, and they mentioned that processes similar to those which formed the cave in Mexico by (Hill, 2000).

In the studied area, the ideal cycle of Fat ha Formation consists of red claystone or sandstone, green marl and gypsum or limestone. This ideal cycle can be seen in many places, but in most cases many incomplete cycles could be seen, which consists only of two lithologies such as red claystone - marl, marl- gypsum and red claystone (Fig. 4). 
In Sangaw sinkholes, the gypsum layers have an average thickness of more than $5 \mathrm{~m}$ and, usually occurs as thick gypsum beds covered by limestone beds, together with the fracturing in the zone, determining the development of the gypsiferous cavities.
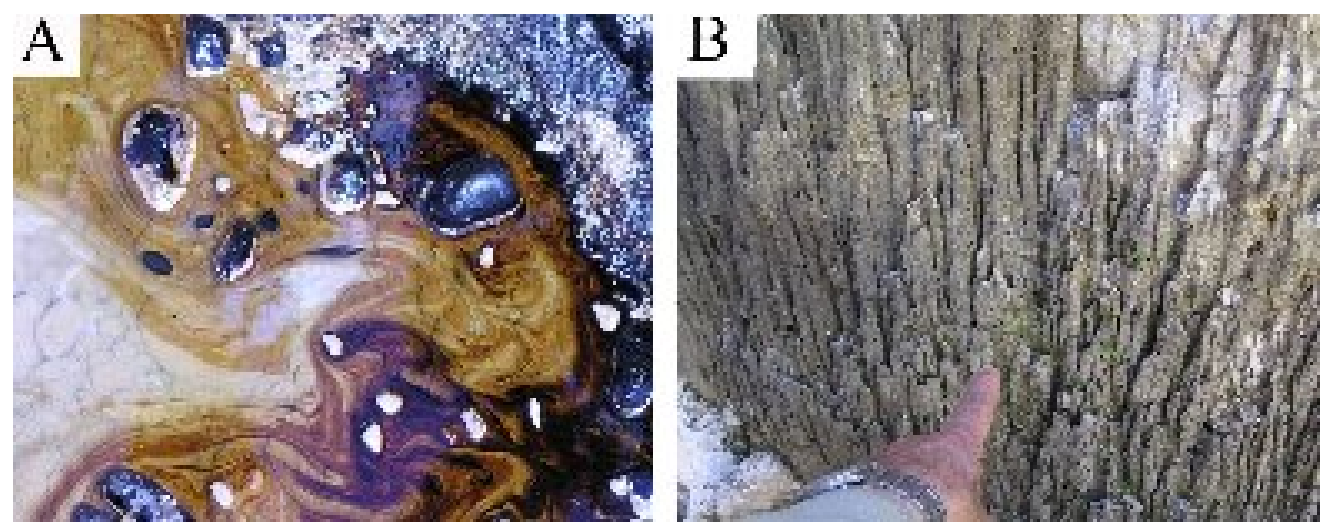

Fig. 8 A: Bitumn mixed with Awa Spi river B: The weathering of the carbonate rocks appears as honeycombs and rills mark which have very rough surface with dull color.

\section{GEOLOGICAL FRAMEWORKE OF KARST}

Andriani and Walsh (2005) classified the sinkholes into six types, the Sangaw sinkholers are related to dissolution type. The origin of Sangaw sinkholes has been proposed in this study to be of acid $(\mathrm{pH}=4)$ (Baba Shekh, 2001) hypogenic speleogenesis due to the presence of $\mathrm{H}_{2} \mathrm{~S}$ rich springs both in the cave and of the surface elsewhere in the area. The hydrological and chemical conditions with processes involved and suggests that hypogenic dissolution of evaporate (gypsum) beds is the best phenomenon in the caves creation. The cave apparently formed by upward solution of the groundwater body in a hypogene setting by (Klimchouk, 2007) he studied some caves in Ukraine as indicated by the following equations

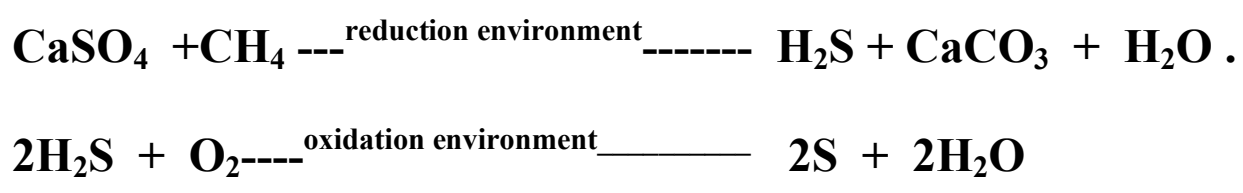




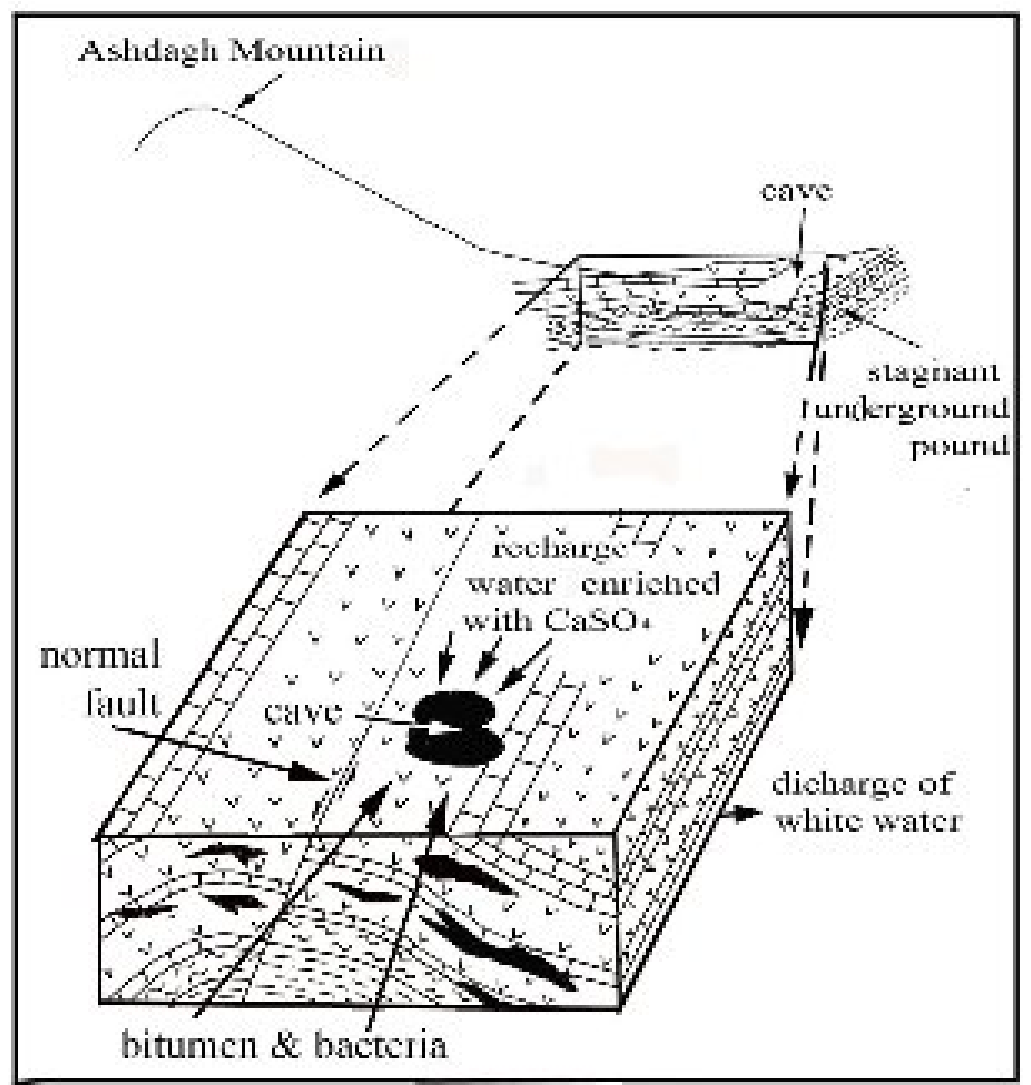

Fig. 9: Conceptual model of the present study showing the effect of stagnant underground pound, recharge water enriched with $\mathrm{CaSO}_{4}$ and upward migration of bitumen from nearby oil traps in Sangaw sinkhole, Ashdagh mountain.

The hypogene processes have relation with Sangaw cave formation, due to the reasons that the strata composed of salt rock and gypsum and due to the dissolution by water containing $\mathrm{H}_{2} \mathrm{~S}$ (acid water). The solution capacity etched out the cave must have came from upwelling, deeper waters in natural convection and carried $\mathrm{H}_{2} \mathrm{~S}$ which reacted with $\mathrm{O}_{2}$ carried down by sinking surface seepage water according to the following equation:

$$
\mathbf{H}_{2} \mathbf{S}+\mathbf{2} \mathrm{O}_{2}---2 \mathbf{H}^{+}+\mathbf{S O}_{2}{ }^{-2}------\mathbf{H}^{+}+\mathbf{H S O}_{4}{ }^{-2}(\mathrm{Hill}, 2000)
$$

Sulphuric acid dissolution represents one of the possible mechanism associated with deep seated hypogene cave development. The sulphuric acid is being produced through the oxidation of $\mathbf{H}_{2} \mathbf{S}$.

The ground water rising into the cave through the permeable beds, due to the stratigraphy and structure of the area which are generated an underground stagnant pond for occurrence of the reaction that emanating enough $\mathrm{H}_{2} \mathrm{~S}$ for hypogene 
generation of the sinkholes and precipitation of secondary native sulfur and gypsum. Upward migration of bitumen is from the nearby oil traps (Fig. 9).

Sangaw Sinkholes probably formed by hypogene processes similar to caves which formed in New Mexico at Guadalupe mountain and Al-Daher sinkholes in Jordan.

\section{DISCUSSION AND CONCLUSIONS}

Klimchouk (2007) described carbonates containing hypogene caves in Brazil do not conform to the typical geological situation of multilayered aquifers. Although subsurface geology is still poorly known in some areas, there is limited potential for the existence of transmissive beds enclosing the carbonates. The low permeability of underline formations limits both the magnitude of regional ground water systems and ascending flow towards the limestone, rising flow would have to be concentrated in localized flow paths, such as faults or joints. At Predjama Cave in Slovenia actual faults themselves do not appear to be important for guiding hypogene development, but shear planes adjacent to faults (Osborne 2008), do appear to be important, and particularly in the many examples of hypogene caves located directly adjacent to faults. The basinal setting of the geological structure suggests a source for the fluids responsible for the origin of extinct hypoginic cave.

Sangaw sinkholes patterns are recognized by different forms of network cave plain, holes and narrow caves are characterized by blind terminations at the ends of cave segments and show no sign of lateral flow. Major horizontal and vertical passages at the wall and floor are restricted to a few places with sequence of chambers linked by much smaller and narrow passages in Sangaw cave. The wall cover generally consists of secondary gypsum, sulfur, bitumen and secondary calcite, smaller caves with similar patterns have been reported in the area.

Karst collapse sediments consist mainly of sulfate and detritus limestone, also with a lensoidal stratified clayey sediments as weathering product could be seen in the area. The weathering of the carbonate rocks is intense inside the cave and appears as honeycombs and rills mark which have very rough surface with dull color. The Sangaw sinkholes are related to dissolution type, because the origin of Sangaw sinkholes has been proposed to be acid hypogenic speleogenesis due to the presence of $\mathrm{H}_{2} \mathrm{~S}$ rich springs both in the cave and as surface spring elsewhere in the area. The hydrological and chemical conditions with processes involved suggest that hypogenic dissolution of evaporate (gypsum) beds is the best phenomenon in the caves creation. The cave apparently formed by upward solution of the groundwater body in a hypogene setting

All Sangaw sinkholes occur in areas underline by impermeable units such as marl. The impermeability of underlying formations limits both the magnitude of 
regional ground water systems and ascending flow towards the limestone. Rising flow would have to be concentrated in localized flow paths, such as major faults or joints. There are great similarities between the Sangaw Sinkholes and caves which formed in New Mexico at Guadalupe mountain and Al-Daher sinkholes in Jordan.

\section{REFERENCES}

Al-Dabbagh, Th. H. and Al-Naqib S. Q., 2009. The Impact of some Geologic Structural Elements on Fuse plug Southeastern Aalignment of Mosul Dam. Iraq Journal of Earth Science, Vol. 9, No. 2, pp. 27 - 38.

Andriani, G. F. and Walsh, N. 2005. The Role of Natural Anthropogenic Processes on the Morphogenetic Evolution of Collapse Sinkholes .Geophysical Research Abstructs, Vol. 7, 08216, European Geosciences Union.

Baba, Shekh, S. M. R., 2001. Hydrogeochemisry of some Springs in Sangaw Chamchamal area. Unpublished M. Sc. Thesis, University of Baghdad, 150 p.

Bellen, R. C. Van., Dunnington, H. V., Wetzel, R. and Morton, D., 1959. Lexique Stratigraphique, Interntional. Asie, Iraq Asia Fascicule, 10a, 333 p.

Buday, T., 1980. In: T. Buday and J. Tyracek., Regional Geology of Iraq, Vol. 1, Stratigraphy, D. G. Geol. Surv. Min. Invest. Publ. Baghdad, 445p.

Buday, T. and Jassim, S. Z., 1987. The Regional Geology of Iraq: Tectonism, Magmatism, and Metamorphism. I. I. Kassab and M. J. Abbas (Eds), Baghdad, $445 \mathrm{p}$.

Calaforra, C. J.M., 1998. Contribution to Knowledge of Ggypsum Karstology. PhD thesis, University of Granada, Spain.

Dunnington, H. V., 1958. Generation, Migration and Dissipation of Oil in Northern Iraq. Arabian Gulf, Geology and Productivity. AAPG Foreign Reprint Series No. 2.

Dublyansky, Y., Spotl C. and Steinbauer C., 2009. Stegbachgraben, A Mineralized Hypogene Cave in the Grossary Valley, Austria. Ukrainian Institute of Speleology and Karstoplogy, Special Paper No. 1, 2009. pp. 117 - 120.

Hill, C. A. 2000. Sulfuric Acid, Hypogene Karst in the Guadalupe Mountaine of New Mexico and West Taxas, U.S.A. In Speleogenisis, Evolution of Karst Aquifers,

Jassim, S. Z. and Goff, J. C. 2006. Geology of Iraq. Published by Dolin, Prague and Moravian Museun, Berno. 341p.

Klimchouk, A. B., Ford D. C., Palmer, A. N., and Dreybroudt, W., (Eds.) 1996. National Speleological Society, Hantsville, Alabama. pp. 309 - 316.

Klimchock, A. B., 1996. Speleogenesis in Gypsum. International Jurnal of Speleology, Vol. 25, No. 3 - 4, pp. $61-82$. 
Klimchouk, A. B., 2000. Speleogenesis of Great Gypsum Mazes in Eastern Ukraine. In Speleogenesis :Evolution of Karst Aquifers, A. B. Klimchock, D. C. Ford, A.N. Palmer, and W. Dreybrodt, (Eds.) National Speleological Socity, Huntsville, Alabama, pp.261- 273.

Kempe, S., Al-Malabeh A. and Henschel H., 2009. Uypogene Karstification in Jordan (Ber gish/Al-Daher cave, Uwaiyed Cave, Beer Al-Malabeh Sinkhole). Ukrainian Institute of Speleology and Karstoplogy, Special Paper No.1, 2009. pp. $253-256$.

Klimchouk, A. B., 2007. Hypogene Speleogenesis: Hydrogeological and Morphogenitic Perspective.-National Cave and Karst Research Institute, Special Paper 1, $106 \mathrm{p}$.

Maala , K.A., 2009:Geomorphology of Al-Jazira Area. Iraqi Bulletin of Geology and Lavrove,. I. 1999. Ordiniskaya Cave. Caves. Permian University. Perm. (In Russia).

Lavrove, I., Maximovitch, E., Maximovitch. N., 2005. Ordiniskaya Cave-the longest Underwater Cave in Russia. In Water Resource and Environmental Problems in Karst. Proceedings of the International Conference and Field Seminars. Belgrade. pp.771 - 776. Mining, Special Issue, No. 3, pp. 5 - 31.

Osborne, R. A. L., 2008. Detailed Morphological Sstudies in Netopirjiv Rov, Predjama Cave : A Hypogene Segment of a Slovenian Cave. Acta Carsologica, Vol. 37, No. 2-3, pp. 65 - 82.

Sissakian, V. K. 2000. Geological Map of Iraq. Sheets No. 1, Scale 1:1000000, Stateestablishment of Geological Survey and Mining. GEOSURV, Baghdad, Iraq. 